Meta

Journal des traducteurs

Translators' Journal

\title{
Nit Orchard, Pickers Wanted
}

\section{Lorne Griffith}

Volume 29, numéro 3, septembre 1984

URI : https://id.erudit.org/iderudit/002971ar

DOI : https://doi.org/10.7202/002971ar

Aller au sommaire du numéro

Éditeur(s)

Les Presses de l'Université de Montréal

ISSN

0026-0452 (imprimé)

1492-1421 (numérique)

Découvrir la revue

Citer cette note

Griffith, L. (1984). Nit Orchard, Pickers Wanted. Meta, 29(3), 327-330.

https://doi.org/10.7202/002971ar

Ce document est protégé par la loi sur le droit d'auteur. L’utilisation des services d'Érudit (y compris la reproduction) est assujettie à sa politique d'utilisation que vous pouvez consulter en ligne.

https://apropos.erudit.org/fr/usagers/politique-dutilisation/
Cet article est diffusé et préservé par Érudit.

Érudit est un consortium interuniversitaire sans but lucratif composé de l'Université de Montréal, l'Université Laval et l'Université du Québec à Montréal. Il a pour mission la promotion et la valorisation de la recherche. https://www.erudit.org/fr/ 
NIT ORCHARD, PICKERS WANTED

A probationary employee in the Translation $\mathrm{Bu}$ reau's English Division receives his first appraisal ${ }^{*}$. INTERIM APPRAISAL - TR-1

English Translation Division Section 1

Employee's name

Lorne GRIFFITH Supervisor's name Jœ ANYREVISER Degree of achievement of work objectives for the period from $16 / 06 / 82$ to $30 / 09 / 82$

Mr. Griffith has worked hard during the review period. His production is good and he willingly accepts the challenge of new fields and short deadlines. However, an examination of his translation in light of the work objectives set reveals a number of major shortcomings.

\section{$1 \& 3$ - ACCURACY}

Mr. Griffith's work contains too many translation errors, many of which could perhaps be avoided by reading the French text more carefully : ... and the importance of personal hygiene ...

... et l'importance de l'hygiène personnelle ...

(should be : the importance of personnel hygiene, as opposed to regional operations hygiene, technical services hygiene and staff development and training hygiene.) The managers' report was comparing the personal cleanliness of members of various correctional Service of Canada components.

... le problème des réviseurs surmenés ...

(brief being submitted to Treasury Board)

... the problem of the overpaid revisers ...

(should be : the problem of the overworked revisers!!)

- The author is deeply indebted to Roger Curtis, Richard Oslund and Malcolm Williams for much of the material used in this satire.
This major mistranslation error (possibly another instance of addition and overinterpretation : see below) was repeated four times in the same text and completely destroyed the central argument of the brief, which was calling for an immediate 37 per cent hike in TR-3 salaries in order to keep abreast of inflation. The gravity of this type of translation error can never be overemphasized enough. Suffice it to say that severe economic hardship could have been caused to the individuals concerned had the mistake gone undetected, and that Mr. Griffith would do well to avoid such unfortunate lapses in future work if he wishes to remain in the employ of the Bureau.

Sometimes the translation error is due to a failure to take fully into account the context : ... who has forced to leave the Ottawa area because of his wife's transfer... (referring to a Department of National Defence employee)

... qui se trouvait dans l'obligation de quitter Ottawa en raison de la mutation de sa femme...

(should be : who was forced to leave the Ottawa area because of his wife's mutation.) The woman in question had been participating in various medical experiments which had considerably altered her appearance and behaviour, and it became necessary to send her to Toronto for treatment because the Royal Ottawa did not have the proper facilities for handling mutations.

In the following example, the context that should have determined the translation of the adjectival element "désceuvré was extratextual $-\mathrm{Mr}$. Griffith should have been more alert to the translation process in English Division :

... en ce qui concerne les $T R-1 s,-2 s$, et $-3 s$ désœuvrés ...

... regarding the idle TR-1s, $-2 \mathrm{~s}$, and $-3 \mathrm{~s} \ldots$

While logic and grammar would suggest that all three noun syntagms of the phrase are equally idle, everyday experience within the section would argue that it is the revisers who are more likely to be idle, not the busy translators anxious to boost production in order to get their promotion. 


\section{$2 \& 3$ - EXPRESSION}

This is the area that gives greatest cause for concern since Mr. Griffith's errors in usage and syntax, together with a sometimes "wooden" rendering of the French text, would appear to cast some doubt on his ability to convey the full factual content, intent and tone of the source text in "clear, idiomatic and readable English Division gibberish". Some of the problems are

\section{ellipsis}

... today is Monday ...

(meaning unclear; needs expansion)

... the earth revolves around the sun ...

(statement is diffuse and lacks precision)

... pavement slippery when wet ...

(ellipsis combined with defective word order and syntax plus comma splice)

... a stitch in time saves nine ...

(level of language, disjointed sentence, overuse of demonstrative pronoun, verbiage, lost nuance and ambiguous antecedent)

.. little Miss Muffet sat on a tuffet eating curds and whey ...

(zeugma, dieresis, polysemy and dysentery)

\section{gallicism}

.. the importance of developing CanadianNipponese relations ...

... l'importance de développer les relations canadonipponèses...

(should be : the importance of developing Canadian-Jap relations)

... the Department of Environment's study of various wildlife elements in Northern Quebec ...

... l'étude du ministère de l'Environnement sur les éléments fauniques divers se trouvant au nord du Québec

(should be : various wildlive components in Northern Quebec)

\section{oversimplification}

... draws a map of collections so that they can be found more easily ...(job description)

... établit un plan des collections pour en faciliter la localisation ...

(should be : establishes a schematic representation of the collections with a view to enhancing their locatability)

level

... "go fuck yourself, man"

... "va te faire foutre, hostie de crosseur" ..

(spontaneous remark made by Quebec Region inmate to his Case Management Officer on learning that his application for early release had been denied)

(should be : "I would like to take this opportunity to express to the Board my profoundest and sincerest opposition to its decision respecting my release date, and to voice the hope that my petition will be more favourably received by the review panel in the not so distant future.")

\section{ambiguity}

... I only sleep with little girls, your honour ...

(text on MNA Gilles Grégoire)

Meaning unclear. Could signify that Gilles Grégoire merely sleeps with little girls as opposed to engaging in the thousand and one other wholesome activities which could be of interest to underage females, such as teaching them to play contract bridge, inviting them out horseback riding in Montmorency Forest on Sunday afternoons or offering them candy wrapped in $\$ 100$ bills to come up to his Quebec City apartment for a bath. Should be recast to avoid ambiguity.

\section{redundancy}

... "Would you please shut the window, Dear. It's raining outside"

(Bravery Report)

Since rain, like other natural phenomena, seldom oc curs indoors, the word "outside" is superfluous and should have been omitted by the careful translator

\section{repetition}

This is an appeal from the unanimous decision of a board of referees which upheld a notice of disqualification from the Commission based on sections 41 and 43 of the Act on the grounds that the claimant left his employment without just cause. The appellant dos not accuse the members of the board of fail ing to observe some rule of natural justice or of act ing beyond their jurisdiction. Instead, to place himself within the framework of section 95 , he accuses them, in terms of the third ground for appeal, of basing their decision on an erroneous finding of fact made in a perverted and capricious manner on the evidence presented before them.

"The", " $a$ ", and "of" are repeated eleven, six and twelve times respectively in the above passage. (The same overuse of the definite and indefinite articles and the preposition "of" has been found in numerous other texts as well.) Mr. Griffith should attempt to vary his vocabulary more so as to avoid monotony in his English.

Speling is also a problem at times :

"phylllostomatidaeism", "zoosporangiophoritism" and "Bacillus thuringiensis" (used twice over a three-year period)

Indeed, some of Mr. Griffith's mispelings seem almost deliberately calculated to embarrass the Bureau

.. the National Parole Bored ...

... funding for Secretary of State pogroms aimed at Jewish and other minority groups...

... following the Canadian Labour Relations Board's recent ruling to the effect that the six and five program did indeed apply to pubic sector employees ..

... as to whether CIDA'S bilateral aids program was successfully meeting the needs and aspirations of 
small-scale farmers in Upper Volta's Uga-Wuga district ...

(also used in the same text : multilateral aids, emergency food aids, sectorial aids and tied and untied aids

The Canadian International Development Agency provides various Third World countries with aid - not AIDS or acquired immune deficiency syndrome, which is a highly fatal and as yet poorly understood condition that attacks the body's immune system, causing previously healthy individuals - mostly homosexual men, intravenous drug users and promiscuous small-scale farmers and rural artisans in underdeveloped countries to be susceptible to a number of life-threatening diseases.

Addition and over-interpretation are a further cause for concern :

the ability to read the comics in the Weekend Citizen and to answer the telephone from time to time are further requirements of this overpaid $\mathrm{CR}$ position.

While no doubt the correlation between the relatively simple duties of the job on the one hand and the high salary offered on the other is tenuous at best, nowhere does the French specifically say that the position is overpaid.

Statistics Canada has once again cooked its figures to show a 2.8 per cent drop in unemployment over the last quarter ...

$A u$ cours du dernier trimestre, Statistique Canada a fait état d'une baisse de $2,8 \%$ du taux de chômage au Canada..

The French text dos not suggest that Statistics Canada used unorthodox statistical procedures to arrive at its unusual and highly implausible figures.

... in addition to her regular duties, the incumbent will be required to provide the Deputy $\mathrm{Di}$ rector-General, Field Operations and Quality Control, and the Director, Program Review and Cost Overruns, together with their respective staffs at the regional and national levels, with a full range of sexual services, to be performed by the incumbent on an ad hoc basis as required. (STY position)

Quite possibly true, but not in the French.

I recommend that $\mathrm{Mr}$. Griffith strive for greater fidelity to the source text.

Punctuation, capitalization and word division are another requiring attention :

... yourfileM4522-2-3(AC)ourfileM02/748revenuecanadacustoms andexcise400youvilesquaremontrealquebecH3Y2C2january 24,1983 attentionmripbourassasubject:authoritytoimportnon-inflammable inflatabledollsofaclassorakindnotmadeincanadaundertarifitem4 100 tearsirs:furthertayourrecentcorrespondenceregarding ...

Mr. Griffith's highly unorthodox format (which he claims constitutes a simple solution to many of the punctuation problems that bedevil the translator), together with his use of single spacing (designed apparently to discourage if not outright eliminate unnecessary revision), would appear to be seriously at odds with many of the recommendations set forth in English Division's Style Sheet. The com- plete absence of capitalization and normal spacing, which seems to have been inspired by certain ouvres of James Joyce, has caused migraine headaches and acute dyslexia among the revision staff and has been a source of some concern among customers as well. Section 1 clients have regretfully informed the Bureau that, notwithstanding the overall high quality of Mr. Griffith's finished translations, they would prefer to have their more important texts assigned to other translators using a more conventional format until this difficulty has been overcome. I suggest that Mr. Griffith make the resolution of this presentation problem the number one priority among his various work objectives.

\section{REVISION AND GUIDANCE}

Mr. Griffith is not nearly so receptive to criticism and guidance as one would like in a TR-1. Whenever instances of awkward or unidiomatic English in his work are brought to his attention, he immediately pulls out fourteen previous texts done within the section containing the very same faulty construction or expression and then begins making sarcastic remarks about the incredible inconsistency in the revision. For example, when the phrase "the responsibilities associated with this position" was condemned as incorrect and unEnglish in a recent text on child-rearing practices among Archambault inmates, Mr. Griffith immediately cited three instances of this major language error in previous texts (two of which had been revised by the section chief himself) and four examples drawn from the work of famous twentieth century writers and leading grammar experts such as W.H. Fowler and Eric Partridge. It is clear that such an approach to language use makes any kind of serious revision virtually impossible because the reviser lives in constant fear of appearing inconsistent if not downright ridiculous. I recommend that $\mathrm{Mr}$. Griffith adopt a more hangdog attitude toward the revision process. Instead of thoughlessly criticizing and finding fault with the numerous revisions introduced by his reviser, perhaps he could stroke his chin with a pensive air and murmur softly, "dear, dear, did I do that ? how foolish of me!..." whenever changes are made to his work.

Another area of concern, and a more serious one, is Mr. Griffith's habit of carefully noting the various errors committed by his revisers and section chief and compiling them in the form of weekly summaries, which he gleefully distributes to his fellow TR-1s and $-2 \mathrm{~s}$ as light reading matter during break. Such a practice tends to undermine the credibility and moral authority of revision, and, if continued, could lead to a serious loss of jobs at the TR-3 level, which is where the big bucks are. Indeed, it has come to my attention that these summaries are now being forwarded by Mr. Griffith to members of Parliament on both sides of the House, with the inevitable result that a small group of publicity-seeking MPs from the Conservative Party have demanded a full and impar- 
tial public inquiry into the problem, calling the thousands of unnecessary (and occasionally incorrect) changes made in the work of TR-1s every year by revisers a billion dollar boondoggle which a Conservative Government, under the dynamic leadership of Brian Mulroney, would soon put an end to if elected. Mr. Griffith would enhance his job security within the Bureau immeasurably by causing to wash Section 1's dirty linen before Parliament.

\section{CLIENT VOCABULARY}

Mr. Griffith continues to refer to the "commissaires" of the National Parole Board as "commissars", claiming that this appellation reflects the true nature and scope of their duties more accurately than does the rather colourless expression "board member", and has steadfastly refused to call members of Parliament anything other than "deputies". No promotion to the TR-2 or working level can be considered for Mr. Griffith until this problem has been satisfactorily resolved.

\section{PRODUCTION}

Mr. Griffith's average production during the review period was 2800 words a day. This is an excellent figure for a beginner, but is somewhat offset by his use of the alternate-page translation system under which every second page of the more difficult texts is left in the original French. I recommend that Mr. Griffith lower his production to 900 or 1000 words a day and try not to omit entire pages.

\section{SUPERVISOR'S SIGNATURE}

I have discussed the foregoing rubbish with the employee.

Signature

Date

\section{EMPLOYEE'S SIGNATURE AND}

\section{COMMENTS}

May you and your children and your children's children spend your entire lives translating nothing but job descriptions for Environment Canada, Quebec Region. (Ancient fourth-century Arabic curse.)

Signature

Date

\section{LORNE GRIFFITH}

